\title{
REGULASI ZAKAT DI INDONESIA; UPAYA MENUJU PENGELOLAAN ZAKAT YANG PROFESIONAL
}

\author{
Muhammad Aziz \\ Institut Agama Islam Negeri \\ Syekh Nurjati, Cirebon \\ E-mail: mohaziv@yahoo.com
}

\author{
Sholikah \\ Institut Keguruan dan Ilmu \\ Pendidikan, Jember \\ E-mail: azizindil@gmail.com
}

\begin{abstract}
In early Islamic history, described the involvement of government in managing it, with almost the same model, all of them can be said to be aimed at the welfare of the people. How does that happen in the context of the management of zakat in Indonesia with a Muslim majority, the actual management of zakat is good, people will be able to prosper. This paper wants to answer two questions, namely; how the history of the regulation of rakat in Indonesia? and secondly, why this charity regulation needs to be regulated in per-laws and regulations in Indonesia? This study used a qualitative approach to the study of comparative descriptive-analytical. The results of this study are that regulation is necessary charity regulated by the State, is in order to improve the effectiveness and efficiency of care in the management of zakat, and increasing the benefits of charity for the public welfare and poverty reduction. The effectiveness of the management of zakat in Indonesia pluralistic requires legal certainty and clarity of regulations that govern them.
\end{abstract}

Keywords: Zakat, Zakat Regulations, Zakat and Welfare 


\section{Pendahuluan}

Zakat dilihat dari perspektif ilmu perekonomian, memiliki korelasi positif pada angka konsumsi yang akan menggerakkan perekonomian. Model konsumsi secara makro ditentukan oleh konsumsi pokok dan konsumsi yang berasal dari pendapatan. Jika dilihat dari sisi mustahiq, maka zakat akan meningkatkan agregat konsumsi dasar, yaitu akumulasi konsumsi pokok.

Hal ini secara logis terjadi akibat akomodasi sistem ekonomi terhadap pelaku pasar yang tidak memiliki daya beli atau mereka yang tidak memiliki akses pada ekonomi. Sehingga mereka memiliki daya beli yang memadai untuk memenuhi kebutuhan dasar. ${ }^{1}$ Kegiatan belanja (konsumsi) merupakan variabel yang sangat positif bagi kinerja perekonomian (economic growth). Ketika perekonomian mengalami stagnasi, seperti terjadi penurunan tingkat konsumsi, kebijakan utama yang diambil adalah bagaimana dapat menggerakkan ekonomi dengan meningkatkan daya beli masyarakat.

Sehingga dapat dikatakan bahwa kemampuan daya beli masyarakat menjadi sasaran utama dari setiap kebijakan ekonomi. ${ }^{2}$ Dengan mekanisme zakat yang baik, peningkatan daya beli masyarakat tetap dapat stabil. Maka zakat memiliki peran yang cukup signifikan untuk menjaga kestabilan perekonomian.

Namun semua itu tidak terasa secara maksimal, jika keberadaan zakat tidak dikelola secara professional, baik ditingkat penarikannya atau ditingkat distribusi dan pengelolaanya. Sampai saat ini, regulasi tentang zakat di Indonesia sudah pernah dikeluarkan oleh pemerintah dan DPR, baik dalam bentuk Undang-undang atau yang tingkatanya lebih rendah. Akan tetapi, masih belum dianggap maksimal dalam implementasinya.

Untuk itu, perlu kiranya sebuah pembahasan komprehensif yang berkaitan dengan keberadaan regulasi zakat di Indonesia ini. Dalam hal ini, yang akan dikaji oleh penulis dalam makalah ini adalah meliputi dua hal; Pertama, bagaimana sejarah regulasi zakat di Indonesia, dan kedua, mengapa regulasi zakat ini perlu diatur dalam per-undang-undangan di Indonesia.

Sadar atau tidak pengkajian tentang regulasi zakat akan banyak menyita tentang perdebatan politik hukum yang sedang berlangsung pada

\footnotetext{
${ }^{1}$ Asnaini, "Membangun Zakat Sebagai Upaya Membangun Masyarakat", La_Riba, Vol. IV, No. 01 Juli 2010, 31.

2 Ali Sakti, Ekonomi Islam: Jawaban atas Kekacauan Ekonomi Modern (Jakarta: Paradigma dan Aqsa Publishing, 2007),
} 
saat undang-undang tersebut disahkan, juga aspek perdebatan argumentasi teologis yang panjang berbicara tentang zakat yang pengelolaannya diserahkan kepada penguasa atau pemimpin, atau bahkan tidak menutup kemungkinan factor politik yang melatarbelakangi masing-masing dalam faksi mazhab, yang menyebabkan perbedaan pendapat tersebut. Tapi itulah yang harus ditelusuri dan dikaji agar memperoleh hasil yang maksimal. 


\section{Sejarah Regulasi Zakat di Indonesia}

Zakat telah manjadi salah satu sumber dana yang penting bagi perkembangan agama Islam sejak masuknya Islam di Indonesia. Pada masa penjajahan Belanda, Pemerintah Kolonial mengeluarkan Bijblad Nomor 1892 tanggal 4 Agustus 1893 yang berisi tentang kebijakan Pemerintah Kolonial mengenai zakat. Tujuan dari dikeluarkannya peraturan ini adalah untuk mencegah terjadinya penyelewengan keuangan zakat oleh para naib. Para naib tersebut bekerja untuk melaksanakan administrasi kekuasaan Pemerintah Kolonial Belanda tanpa memperoleh gaji untuk membiayai kehidupan kereka. ${ }^{3}$

Kemudian pada tanggal 6 Februari 1905 dikeluarkan Bijblad Nomor 6200 yang berisi tentang pelarangan bagi seorang pegawai dan priyayi pribumi untuk membantu pelaksanaan zakat. Hal ini bertujuan untuk semakin melemahkan kekuatan rakyat yang bersumber dari zakat tersebut. Setelah kemerdekaan Indonesia, perkembangan zakat menjadi lebih maju. Meskipun Negara Republik Indonesia tidak berdasarkan pada salah satu falsafah tertentu, namun falsafah negara kita dan pasal-pasal Undang-Undang Dasar (UUD) 1945 memberikan kemungkinan bagi pejabat-pejabat negara untuk membantu pelaksanaan pengelolaan zakat. ${ }^{4}$

Pada masa di berlakukannya UUDS 1950 perkembangan zakat tidak surut. Menteri Keuangan Republik Indonesia saat itu, yaitu M. Jusuf Wibisono menulis sebuah makalah yang dimuat pada majalah Hikmah Jakarta (1950) yang mengemukakan gagasannya untuk memasukkan zakat sebagai salah satu komponen sistem perekonomian Indonesia. Selain itu di kalangan anggota parlemen terdapat suara-suara yang menginginkan agar masalah zakat diatur dengan peraturan perundangundangan dan diurus langsung oleh pemerintah atau negara. ${ }^{5}$

Demikian pula menurut Prof. Hazairin dalam ceramahnya di Salatiga pada tanggal 16 Desember 1950 menyatakan bahwa dalam penyusunan ekonomi Indonesia, selain komponen-komponen yang telah ada dalam sistem adat kita yaitu gotong royong dan tolong menolong, zakat juga sangat besar manfaatnya. Sedangkan untuk tata cara pelaksanaanya perlu

\footnotetext{
3 Ancas Sulchantifa Pribadi, Pelaksanaan Pengelolaan Zakat Menurut Undang-Undang Nomor 38 Tahun 1999 Tentang Pengelolaan Zakat (Studi Di Baz Kota Semarang), Tesis Program Studi Magister Kenotariatan Universitas Diponegoro Semarang Tahun 2006, tesis tidak dipublikasikan. Keterangan lebih lengkap tentang sejarah regulasi zakat di Indonesia dapat dibaca pada bukunya Amelia Fauzia, Faith and the State: A History of Islamic Philanthropy in Indonesia, (Leiden: Brill's Southeast Asian Library, 2013).

${ }^{4}$ Ibid.

${ }^{5}$ Ibid.
} 
untuk disesuaikan dengan kehidupan di Indonesia, misalnya apabila diadakan Bank Zakat, yang akan menampung dana zakat jika tidak ada lagi golongan yang menerima dari 8 golongan mustahiq, maka akan sangat bermanfaat. Dari Bank Zakat tersebut dapat disalurkan pinjaman jangka panjang bagi rakyat miskin guna membangun lapangan hidupnya yang produktif. Zakat yang diselenggarakan dan diorganisasikan dengan baik, akan sangat bermanfaat tidak hanya bagi umat Islam tetapi juga bagi masyarakat non muslim. ${ }^{6}$

Perhatian pemerintah terhadap lembaga zakat semakin meningkat pada tahun 1968. Yaitu dengan dikeluarkannya Peraturan Menteri Agama Nomor 4 dan Nomor 5 Tahun 1968, masing-masing tentang pembentukan Badan Amil Zakat dan Baitul Mal (Balai Harta Kekayaan) di tingkat pusat, propinsi, dan kabupaten/kota.

Setahun sebelumnya yaitu pada tahun 1967, pemerintah telah menyiapkan RUU Zakat yang akan diajukan kepada DPR untuk disahkan menjadi undang-undang. RUU tersebut disiapkan oleh Menteri Agama dengan harapan akan mendapat dukungan dari Menteri Sosial dan Menteri keuangan. Karena masalah ini erat kaitannya dengan pelaksanaannya pasal 34 UUD 1945 dan masalah pajak. Namun gagasan tersebut ditolak oleh Menteri Keuangan yang menyatakan bahwa peraturan mengenai zakat tidak perlu dituangkan dalam undang-undang, tetapi cukup dengan Peraturan Menteri Agama saja. Dengan pernyataan Menteri Keuangan tersebut, Menteri Agama mengeluarkan keputusan yang berisi tentang penundaan pelaksanaan Peraturan Menteri Agama Nomor 5/1968.

Presiden Indonesia saat itu, Presiden Suharto, pada malam peringatan Isra' Mi'raj di Istana negara tanggal 22 Oktober 1968, mengelurkan anjuran untuk menghimpun zakat secara sistematis dan terorganisasi. Bahkan secara pribadi beliau menyatakan diri bersedia menjadi 'amil zakat tingkat nasional. ${ }^{7}$ Kemudian dengan dipelopori oleh Pemerintah Daerah Khusus Ibukota Jakarta Raya, yang pada waktu itu dipimpin oleh Gubernur Ali Sadikin, berdirilah Badan Amil Infaq dan Shadaqah (BASIS). Hal ini diikuti oleh berbagai propinsi di Indonesia, yaitu dengan terbentuknya Badan Amil Zakat yang bersifat semi pemerintah melalui surat keputusan Gubernur. Badan tersebut tampil dengan nama yang berbeda-beda disetiap daerah, namun pada umumnya mengambil nama

\footnotetext{
${ }^{6}$ M. Daud Ali, Sistem Ekonomi Islam Zakat dan Wakaf, (Jakarta: UI Press, 1988), 36.

7 Djohan Effendi dkk, Agama dalam Pembangunan Nasional; Himpunan Sambutan Presiden Subarto, (Jakarta: CV. Kuning Mas, 1984).
} 
BAZIS seperti di Aceh (1975), Sumatra Barat (1977), Lampung (1975), Jawa Barat (1974), Kalimantan Selatan (1977), Kalimantan Timur (1972), Sulawesi Utara, Sulawesi Selatan (1985), dan Nusa Tenggara Barat.

Untuk meningkatkan pembinaan terhadap BAZIS, pada tahun 1991 Menteri Dalam Negeri dan Menteri Agama mengeluarkan Keputusan Bersama No. 29 dan 47 tentang Pembinaan Badan Amil Zakat, Infaq, Shadaqah, yang diikuti dengan instruksi Menteri Dalam Negeri No.7 tahun 1991 tentang Pelaksanaan Keputusan Bersama tersebut.

Kemudian pada tanggal 7 Januari 1999 dilaksanakan Musyawarah Kerja Nasional I Lembaga Pengelola ZIS dan Forum Zakat yang dibuka oleh Presiden Habibie. Salah satu hasil dari musyawarah tersebut adalah perlunya dipersiapkan UU tentang Pengelolaan Zakat. Hasil musyawarah tersebut ditindak lanjuti dengan Surat Menteri Agama No. MA/18/111/1999 mengenai permohonan persetujuan prakarsa penyusun RUU tentang Pengelolaan Zakat. Permohonan tersebut disetujui melalui surat Menteri Sekretaris Negara RI No. B. 283/4/1999 tanggal 30 April 1999. Pembahasan mengenai RUU tentang Pengelolaan Zakat dimulai tanggal 26 Juli 1999 yaitu dengan penjelasan pemerintah yang di awali oleh Menteri Agama. Mulai tanggal 26 Agustus sampai dengan tanggal 14 September 1999 diadakan pembasan substansi RUU tentang Pengelolan Zakat dan telah di setujui oleh DPR RI dengan keputusan DPR RI Nomor 10/DPR-RI/1999. Dan melalui surat Ketua DPR RI Nomor RU.01/03529/DPR-RI/1999 tanggal 14 September 1999 disampaikan kepada Presiden untuk ditandatangani dan disahkan menjadi undang-undang. Pada tanggal 23 September 1999 diundangkan menjadi Undang-Undang Nomor 38 tahun 1999 tentang Pengelolaan Zakat. Undang-Undang Nomor 38 Tahun 1999 tentang Pengelolaan Zakat ini berisi $10 \mathrm{Bab}$ dan 25 Pasal. Rincian dari Undang-Undang Nomor 38 Tahun 1999 tentang Pengelolaan Zakat adalah sebagai berikut: ${ }^{8}$

- Bab I Ketentuan Umum ( Pasal 1,2,3 )

- Bab II Asas dan Tujuan (Pasal 4,5).

- Bab III Organisasi Pengelolaan Zakat ( Pasal 6,7,8,9,10 )

- Bab IV Pengumpulan Zakat ( Pasal 11,12,13,14,15)

- Bab V Pendayagunaan Zakat ( Pasal 16,17)

- Bab VI Pengawasan ( Pasal 18,19,20)

- Bab VII Sanksi ( Pasal 21)

8 M. Mansyhur Amin, Pengelolaan Zakat dan Permasalahannya di Indonesia, (Jakarta: Direktorat Urusan Agama Islam Departemen Agama, 2000). 
- Bab VIII Ketentuan-Ketentuan Lain ( Pasal 22,23)

- Bab IX Ketentuan Peralihan ( Pasal 24)

- Bab X Ketentuan Penutup ( Pasal 25 )

Setelah diberlakukannya undang-undang tersebut pemerintah mengeluarkan peraturan pelaksanaan melalui Keputusan Menteri Agama Nomor 581 Tahun 1999 tentang Pelaksanaan Undang-undang Nomor 38 Tahun 1999. Kamudian diikuti dengan dikeluarkannya Keputusan Direktur Jenderal Bimbingan Masyarakat Islam dan Urusan Haji Nomor D/291 Tahun 2000 tentang Pedoman teknis Pengelolaan Zakat.

Dapat dikatakan bahwa, sejarah tentang regulasi zakat di Indonesia diwarnai dengan pergulatan yang sangat panjang, serta tarik ulur antara kepentingan Islamis politik dan kepentingan Islamis kultural dan bahkan kepentingan kolonial penjajah dalam upaya mengatur undang-undang zakat. Hal itu dimulai dari zaman kolonial penjajah, dengan adanya Bijblad Nomor 1892 tanggal 4 Agustus 1893 yang berisi tentang kebijakan Pemerintah Kolonial mengenai zakat, sebuah aturan yang terkesan berupaya mengatur tentang sistem administrasi zakat, akuntabilitas laporanya. Kemudian dikeluarkan Bijblad Nomor 6200 yang berisi tentang pelarangan bagi seorang pegawai dan priyayi pribumi untuk membantu pelaksanaan zakat.

Selanjutnya adalah era pasca-penjajahan, dalam hal ini perhatian pemerintah terhadap lembaga zakat semakin meningkat pada tahun 1968. Yaitu dengan dikeluarkannya Peraturan Menteri Agama Nomor 4 dan Nomor 5 Tahun 1968, masing-masing tentang pembentukan Badan Amil Zakat dan Baitul Mal (Balai Harta Kekayaan) di tingkat pusat, propinsi, dan kabupaten/kota, namun demikian keputusan ini diikuti oleh keputusan Menteri Agama baru yang berisi tentang penundaan pelaksanaan Peraturan Menteri Agama Nomor 5/1968.

Masih pada tahun yang sama, Presiden Suharto, pada malam peringatan Isra' Mi'raj di Istana negara tanggal 22 Oktober 1968, mengelurkan anjuran untuk menghimpun zakat secara sistematis dan terorganisasi. Anjuran ini kemudian ditindaklanjuti oleh oleh Pemerintah Daerah Khusus Ibukota Jakarta Raya, yang pada waktu itu dipimpin oleh Gubernur Ali Sadikin, untuk mengelola zakat secara professional, maka berdirilah Badan Amil Infaq dan Shadaqah (BASIS). Hal ini diikuti oleh berbagai propinsi di Indonesia, yaitu dengan terbentuknya Badan Amil Zakat yang bersifat semi pemerintah melalui surat keputusan Gubernur. Badan tersebut tampil dengan nama yang berbeda-beda disetiap daerah, namun pada umumnya mengambil nama BAZIS seperti di Aceh (1975), Sumatra Barat (1977), Lampung (1975), Jawa Barat (1974), Kalimantan 
Selatan (1977), Kalimantan Timur (1972), Sulawesi Utara, Sulawesi Selatan (1985), dan Nusa Tenggara Barat. Sampai akhirnya munculnya UU Nomer 38 Tahun 1999 dan UU Nomer 23 tahun 2011 tentang pengelolaan zakat.

\section{UU Nomor 23 Tahun 2011 tentang Pengelolaan Zakat}

a. Dinamika dan Perdebatan Parpol dalam UU Pengelolaan Zakat

Setelah membahas sejarah tentang regulasi zakat di Indonesai, selanjutnya adalah pembahasan tentang undang undang tentang zakat yang sampai hari ini masih berlaku, akan tetapi dianggap menyisakan beberapa problematika yang tidak sedikit.

Pembahasan RUU tentang Pengelolaan Zakat, Infaq dan Shodaqoh diawali degan Rapat Kerja antara Komisi VIII DPR RI dengan Pemerintah pada Senin, 28 Maret 2011 Masa Persidangan III Tahun Sidang 2010-2011 yang menyepakati jadwal dan persidangan pembahasan serta mengesahkan Panitia Kerja (Panja) RUU tentang Pengelolaan Zakat, Infaq dan Shodaqoh. Selanjutnya pembahasan dilakukan melalui Rapat Dengar Pendapat (RDP) Panja Panja Komisi VIII DPR RI dengan Pemerintah sebanyak 7 (tujuh) kali dan Rapat Konsinyering 2 (dua) kali, terhitung mulai tanggal 28 Maret 2011 sampai dengan 17 Oktober 2011. Setelah substansi RUU tentang pengelolaan zakat, infaq dan shadaqah dicermati sebagaimana kesempatan Panja Komisi VIII DPR RI dengan Panja Pemerintah pada Rapat Konsiyering hari Jumat, 18 Juni 2011 Pukul 21.00 bahwa judul RUU tentang Pengelolaan Zakat, Infaq dan Shodaqoh berubah menjadi Rancangan Undang-Undang tentang Pengelolaan Zakat, sedangkan pengaturan pengelolaan zakat, infaq dan shodaqoh dan dana sosial keagamaan lainnya diatur sebagai norma tambahan (extra norms); sebagaimana rumusan RUU tentang Pengelolaan Zakat Pasal 2 8 ayat (1), (2), (3).

Rapat Kerja Komisi VIII DPR dengan Pemerintah (Menteri Agama, Menteri Keuangan (terwakili), Menteri Dalam Negeri (terwakili), Menteri Hukum dan Hak Asasi Manusia) dalam Pengambilan Keputusan Tingkat I terhadap RUU tentang

\footnotetext{
9 Salah satu buktinya bahwa undang-undang ini dianggap problematic adalah, sampai tulisan ini selesai ditulis, UU No 23 Tahun 2011 tentang zakat masih ngendon di Mahkamah Konstitusi, karena di uji oleh beberapa kelompok masyarakat yang tidak terima dengan UU tersebut. Lihat, http://id.berita.yahoo.com/laica-marzuki-uu-zakatmasih-menggantung-062929412.html? ucs_mail_preview_popupsignin=1, (akses pada 22 Oktober 2013).
} 
Pengelolaan Zakat dipimpin Ketua Komisi VIII, Abdul Kadir Karding, di Gedung Nusantara I DPR. RUU tentang Pengelolaan Zakat ini akan diajukan ke Sidang Paripurna Dewan berdasarkan persetujuan dari seluruh fraksi yang ada di Komisi VIII saat Pengambilan Keputusan Tingkat I terhadap RUU tentang Pengelolaan Zakat yang disampaikan oleh masing-masing juru bicara fraksi dalam pandangan mini fraksinya. ${ }^{10}$

Juru bicara fraksi Partai Demokrat, Nany Sulistyani Herawati mengusulkan hendaknya pendekatan dalam pengelolaan zakat sebaiknya lebih difokuskan pada perspektif pemberdayaan dan bersifat jangka panjang dibanding bersifat santunan dan sementara. "Penyaluran zakat harus tepat sasaran dan penggunaan zakat mesti dititikberatkan pada kegiatan produktif agar dapat memberikan efek sosial ekonomi yang nyata dan signifikan bagi penerima zakat. Karena itu, fraksi Partai Demokrat sangat mendukung dan mendorong upaya pengelolaan zakat yang didasarkan syariah Islam dan dikelola secara profesional dan amanah. ${ }^{11}$

Zulkarnaen Djabar dari fraksi Partai Golkar berpendapat, zakat sebagai salah satu nilai instrumental dalam ekonomi Islam dapat menjadi instrumen dalam meningkatkan kesejahteraan rakyat asalkan dikelola dengan baik dan berbanding lurus dengan nilai instrumental ekonomi Islam lainnya. Hal ini berarti menjadikan zakat sebagai bagian dari sumber dana jaminan sosial yang efektif juga dibutuhkan peran negara sebagai entitas yang mengatur segala yang terkait kekosongan hukum, dan memberikan sebuah regulasi yang baik demi tercapainya pengelolaan potensi-potensi yang ada di masyarakat. ${ }^{12}$

Sementara Ina Amania dari fraksi -Partai Demokrasi Indonesia Perjuangan (PDI-P) dalam pandangan fraksi mininya memberikan catatan dan sikap kritis reflektif terhadap RUU Zakat. Pertama, perihal prinsip kesukarelaan dalam melaksanakan ajaran agama. Artinya, pengambilan zakat adalah berdasar kesukarelaan dan kesadaran menjalankan agama bagi pemeluknya. "Ini berarti tidak boleh ada paksaan bagi pemeluk agama Islam untuk menyerahkan zakat hanya pada satu kelembagaan saja, dan Umat Islam dapat memilih amil yang

10 Puji Kurniawan, "Legislasi Undang-Undang Zakat", Al-Risalah, Vol.13, No.1 Mei 2013, 12.

11 Risalah Resmi, Rapat Paripurna ke-9 2011-2012, Kamis, 27 Oktober 2011, Pukul 09.00 WIB s/d Selesai di Ruang Rapat Paripurna Gedung Nusantara II Jl. Jend. Gatot Subroto-Jakarta.

12 Ibid. 
dipercayainya untuk selanjutnya dikumpulkan harta zakat untuk kemaslahan umat, sesuai aturan agama (fiqih). Kedua, mengenai pajak dan zakat perlu didudukkan sesuai perihal dalam koridornya masingmasing. Pajak adalah bentuk tanggungjawab rakyat atas kelangsungan kehidupan bangsa dan negaranya. Berdasarkan Pasal 23A UUD 1945, pajak dan pungutan lain yang bersifat memaksa adalah untuk keperluan negara diatur dengan undang-undang. Dengan demikian, jelasnya, prinsip pajak adalah memaksa. ${ }^{13}$

Ina Amania menambahkan, uang pajak merupakan salah satu sumber pemasukan APBN yang diambil dari setiap wajib pajak, tanpa memperhatikan agama yang dianutnya. Oleh sebab itu, APBN harus digunakan untuk kemakmuran rakyat secara umum.

Sementara Menteri Agama, Suryadharma Ali dalam sambutannya mengatakan, undang-undang pada hakekatnya adalah hukum positif yang dilahirkan melalui proses politik yang dibuat dalam rangka melaksanakan konstitusi, tetapi karena zakat adalah ketentuan agama Islam maka undang-undang mengenai zakat harus tetap mengacu kepada ketentuan syariat Islam. Oleh karena langkah penyempurnaan UU No.38 Tahun 1999 tentang Pengelolaan Zakat yang dilakukan oleh DPR bersama pemerintah sekarang ini merupakan hal yang sangat tepat. Tidak saja dilihat dari kepentingan politik kenegaraan melainkan pula kepentingan umat Islam.

Menurutnya, peran pemerintah yang dalam hal ini secara fungsional dilaksanakan oleh kementerian agama akan berperan sebagai kementerian yang melakukan pembinaan, pengawasan, dan pengendalian pengelolaan zakat yang dilakukan oleh Baznas dan LAZ. Dengan demikian, pemerintah akan bertindak sebagai regulator dan Baznas serta LAZ sebagai operator.

Setelah melakukan rapat-rapat yang cukup panjang dan melelahkan, akhirnya hasil pembahasan RUU tentang Pengelolaan Zakat dilaporkan kepada Komisi VIII DPR RI, pada tanggal 19 Oktober 2011 dalam forum Rapat Kerja dengan agenda utama mendengarkan laporan hasil Panitia Kerja atas pembahasan RUU tentang Pengelolaan Zakat.

Namun setelah penyampaian laporan hasil pembahasan Rancangan Undang-Undang Tentang Pengelolaan Zakat ada beberapa fraksi yang tidak sepakat dengan pengesahan undang-undang itu karena dinilai ada beberapa pasal yang tidak sesuai dengan substansi (ruh) yang

${ }^{13}$ Puji Kurniawan, Legislasi Undang-Undang Zakat ..., 112. 
dikehendaki oleh undang-undang tersebut diantaranya adalah fraksi Partai Keadilan Sejahtera.

Menurut Rahman Amin dari fraksi PKS mengatakan Komisi VIII telah berhasil melakukan lompatan yang cukup signifikan terkait RUU Pengelolaan Zakat jika melihat Undang-Undang Nomor 38 Tahun 1999 sudah agak sedikit ketinggalan dari apa yang dilakukan oleh umat Islam secara keseluruhan. Namun fraksi PKS menyarankan ada penambahan kata dalam Pasal 13 ayat (3) poin a dan poin b ini. Sehingga bisa mengakomodasi atau mengakomodir lembaga atau yayasan-yayasan yang sudah lama berkontribusi di tengah umat. Yaitu dengan menambah kata sedikit yaitu "atau". Dan Pasal 18 ayat (2) bunyinya: "Izin sebagaimana dimaksud pada ayat (1) hanya diberikan apabila memenuhi persyaratan paling sedikit (a) terdaftar sebagai organisasi kemasyarakatan Islam yang mengelola bidang pendidikan, dakwah, dan sosial; (b) berbentuk lembaga berbadan hukum.

Fraksi PKS mengusulkan kata "berbadan hukum" ini tambah kata "atau berbadan hukum", Sehingga lembaga amil zakat yang sudah ada, yayasan yang sudah ada di masjid-masjid di kota-kota atau dilanggar langgar ini tetap akan eksis karena dia telah memberikan kontribusinya di tengah umat demikian lama. ${ }^{14}$

Iskan Qolba Lubis juga menambahi bahwa pasal 43 kurang relevan. Karena Pasal 43 ayat (4) "LAZ sebagaimana dimaksud pada ayat (3) wajib menyesuaikan diri paling lambat 1 tahun terhitung sejak undang-undang ini diundangkan". Artinya sesudah 1 tahun, Dompet Dhuafa, PKPU, itu yang sudah berperan di masyarakat akan mati secara sistemik.Dalam hal ini iskan menaruh curiga kepada Sekjen Kementerian Agama karena draf yang diajukan oleh DPR tidak ada istilah pembatasan hanya ormas. Kemudian yang di draf yang diajukan oleh Baznas juga Pasal 26 disebut ormas dan yayasan. Jadi draf yang diajukan oleh DPR dan Baznas itu sangat mengakomodir ormas. Sehingga PKS dengan jelas tidak setuju kalau ini dibatasi, walaupun masih ada kesempatan judicial review, tapi ini tidak sesuai dengan ruh dari undang-undang bahwa kita menginginkan peran masyarakat dibuka seluas-luasnya. ${ }^{15}$

\footnotetext{
14 Risalah Resmi, Rapat Paripurna ke-9 2011-2012, Kamis, 27 Oktober 2011, Pukul 09.00 WIB s/d Selesai di Ruang Rapat Paripurna Gedung Nusantara II Jl. Jend. Gatot Subroto-Jakarta, 20-21.

15 Risalah Resmi, Rapat Paripurna ke-9 2011-2012, Kamis, 27 Oktober 2011, Pukul 09.00 WIB s/d Selesai di Ruang Rapat Paripurna Gedung Nusantara II Jl. Jend. Gatot Subroto-Jakarta, 26.
} 
Murady Darmansjah dari Partai Hanura mengomentari bahwa usul dari PKS itu perlu dicermati dan dipertiimbangkan. Karena masalah shodaqoh, masalah zakat, adalah hubungan antara manusia dengan Tuhan. Tidak bisa terlalu banyak diintervensi oleh suatu permasalahan yang diatur dengan undang-undang. ${ }^{16}$ Akan tetapi hal ini di interupsi oleh Abdul Kardir Karding dari Fraksi Partai Kebangkitan Bangsa (PKB) dengan menyebutkan bahwa menjelaskan langkah-langkah yang sudah dilakukan dalam artian prosedur yang sudah ditempuh di dalam penyusunan undang-undang ini dan telah melakukan uji publik di tiga daerah (Provinsi Aceh, Gorontalo dan Jawa Barat) setelah itu di Komisi VIII telah melakukan Rapat Internal untuk meminta masukan-masukan ketika rapat kerja tanggal 19 Oktober 2011 yang lalu, bersama Menteri Agama dan beberapa menteri terkait kita sudah menyepakati menggunakan kata akhir fraksi-fraksi di komisi. Dan masing-masing fraksi telah mengajukan kata akhir dan menyetujui Rancangan Undang-Undang dibawa ke forum untuk disahkan. Secara formal seluruh fraksi dari 9 (sembilan) fraksi yang ada sesungguhnya telah menyetujui secara resmi dan bertanda tangan secara resmi bahwa undang-undang ini akan disepakati disetujui.

Ach Rubaie juga menyatakan Pada intinya spirit undang-undang ini memperkuat peranan masyarakat untuk berpartisipasi di dalam mengumpulkan dan mendistribusikan zakat, yaitu dengan membentuk LAZ. Jadi kalau ada anggapan tidak memberikan peran kepada masyarakat, saya kira memang belum menangkap secara sungguhsungguh substansi dari RUU ini. Maka dari itu, sepenuhnya Fraksi PAN setuju terhadap laporan yang sudah disampaikan oleh Ketua Komisi VIII. ${ }^{17}$

Disamping itu Aria Bima dari Partai Demikrasi Perjuangan (PDIP) memberi masukan dengan mengatakan menghormati dan menghargai atas disahkannya Rancangan Undang-Undang tentang Pengelolaan Zakat, karena itu merupakan suatu hal yang penting bagi umat Islam di dalam menjalankan ibadah sesuai dengan syariat Islam. Namun hal yang perlu disampaikan bahwa ada sesuatu yang penting dipikirkan secara bersama-sama sebagai bangsa yang plural, sebagai

\footnotetext{
16 Risalah Resmi, Rapat Paripurna ke-9 2011-2012, Kamis, 27 Oktober 2011, Pukul 09.00 WIB s/d Selesai di Ruang Rapat Paripurna Gedung Nusantara II Jl. Jend. Gatot Subroto-Jakarta, 24.

17 Risalah Resmi, Rapat Paripurna ke-9 2011-2012, Kamis, 27 Oktober 2011, Pukul $09.00 \mathrm{WIB}$ s/d Selesai di Ruang Rapat Paripurna Gedung Nusantara II Jl. Jend. Gatot Subroto-Jakarta, 24.
} 
bangsa yang sesuai dengan amanat konstitusi kita, kebhinnekaan, dimana persamaan di setiap persoalan bangsa ini baik menyangkut penanggulangan kemiskinan, baik menyangkut masalah-masalah bencana alam yang sering turut bergotong royong secara bersamasama menyelesaikan persoalan,dan perlu adanya undang-undang juga yang menyangkut kegotong-royongan kita sebagai bangsa dan berharap dalam forum yang terhormat ini sebagai Anggota Dewan ataupun mengharap kepada Saudara Pimpinan, DPR juga bisa menginisiasi usul inisiatif Undang-Undang Kegotongroyongan yang lebih pluralis, yang lebih bisa menyelesaikan persoalan-persoalan bangsa sesuai dengan amanat konstitusi. Misalnya bagaimana fakir miskin dan anak terlantar ini dibiayai dan dihidupi oleh negara. Perlu adanya suatu undang-undang semacam zakat tapi lepas dari sekatsekat premodial dan lepas sekat-sekat kesukuan. sehingga kebersamaan sebagai bangsa itu bisa dijamin dan dilindungi oleh undang-undang dan sosialisasikan serta mengimplementasikan kebhinnekaan, pluralisme, Pancasila, dan Undang-Undang Dasar 1945 di dalam kehidupan berbangsa dan bernegara kita.

Dolfie OFP dari fraksi PDI-P juga mencermati mencermati mengenai hak lain di Pasal 1 ayat (2) ketentuan umum. Di situ disebukan zakat adalah harta yang wajib dikeluarkan oleh seorang muslim atau badan usaha dan seterusnya dan seterusnya. Tidak ada pengertian yang jelas tentang badan usaha yang wajib memberikan zakat. Dolfie menginginkan dicantumkannya batasan yang jelas tentang badan usaha mana yang wajib memberikan zakat, karena di dalam undang-undang ini penjelasan yang menjelaskan badan usaha hanya ada di Pasal 4 ayat (3) disebutkan bahwa badan usaha meliputi badan usaha yang tidak berbadan hukum dan yang berbadan hukum seperti perseroan terbatas. Sehingga semua badan usaha itu wajib memberikan zakat. Ini harus ada batasan yang jelas, badan usaha mana yang tunduk terhadap undang-undang. ${ }^{18}$

Kemudian Sekjen Menteri Agama menyampaikan tambahan informasi sesuai dengan beberapa pendapat yang disampaikan oleh Anggota dari DPR RI. Khusus Pasal 18 terkait dengan izin Lembaga Amil Zakat yang dimiliki oleh masyarakat ini persyaratan yang dimintakan bersifat kumulatif, itu yang disepakati. Kumulatif dalam

18 Risalah Resmi, Rapat Paripurna ke-9 2011-2012, Kamis, 27 Oktober 2011, Pukul 09.00 WIB s/d Selesai di Ruang Rapat Paripurna Gedung Nusantara II Jl. Jend. Gatot Subroto-Jakarta, 24. 
bunyi pembentukan LAZ wajib mendapat izin menteri atau pejabat yang ditunjuk oleh menteri”. Dan pada ayat berikutnya: Izin sebagaimana dimaksud pada ayat (1) hanya diberikan apabila memenuhi persyaratan paling sedikit dan ini kumulatif. Yang pertama adalah terdaftar sebagai organisasi kemasyarakatan Islam yang mengelola bidang pendidikan dakwah dan sosial. Penjelasannya, lembaga zakat oleh masyarakat tidak diperkenankan dikelola oleh individu. Oleh karenanya kata organisasi adalah mutlak. Yang kedua, kita tidak memperkenankan juga organisasi ini bukan berbasis kemasyarakatan Islam.

Oleh karenanya kata yang kami pilih adalah organisasi kemasyarakatan Islam. Hal ini juga sesuai dengan Undang-Undang Tahun 1985 yang sedang dalam proses perbaikan, tentang Organisasi Kemasyarakatan. Bunyinya adalah organisasi kemasyarakatan agama dan kita tambahkan Islam. Kemudian kumulatifnya pada b dia harus berbadan hukum. Hal ini terkait dengan kewenangan-kewenangan terutama dalam pengalihan asset. Apabila dalam satu dan lain hal terjadi kevakuman atau lembaga yang kita tunjuk LAZ ini suatu waktu tidak berfungsi atau dipailitkan. Di dalam badan hukum akan jelas diatur kemana hak-hak dari kewajiban asset ini harus dilarikan. Tanpa perikatan badan hukum ini akan sulit. Sebab organisasi kemasyarakatan Islam yang nanti akan didaftarkan di Kementerian Dalam Negeri tidak mengatur kedudukan asset. Dengan demikian kita ingin LAZ yang dibentuk oleh masyarakat apabila satu dan lain hal itu maka seluruh asset dan hak kewajiban dari organisasinya akan diatur sesuai dengan Undang-Undang Yayasan dan pilihan lain memang ada perhimpunan, perkumpulan, tapi yayasan adalah pilihan dari badan hukum yang akan cocok dengan Lembaga Amil Zakat.

Jadi jika menambahkan kata "atau" untuk kumulatif a dan b, dampaknya adalah kemungkinan tidak akan sinkron dalam pasal-pasal lain. Apabila a tidak dipenuhi maka b boleh dipenuhi, itu artinya Lembaga Amil Zakat boleh dikelola bukan oleh umat Islam. Ini juga menjadi dampak yang tidak baik bagi masyarakat.

Sebab lembaga yang disebut berbadan hukum tidak diharuskan lembaga itu dimiliki oleh umat Islam. Jadi kalau pilihannya b ini atau, maka a tidak berfungsi, b berfungsi, kita harus juga melihat badan hukum yayasan tidak harus milik umat Islam. tapi dia boleh membuka Lembaga Amil Zakat. Kalau itu pilihannya atau. Jadi kami melihat usul yang telah disepakati dalam rapat di tingkat komisi adalah sudah tepat, kita mempersyaratkan organisasi kemasyarakatan Islam pada 
saat yang sama untuk menjamin asset dan kewenangan-kewenangan harta yang dimiliki pada Lembaga Amil Zakat maka dia harus berbadan hukum. Apabila terjadi satu dan lain hal kepailitan maka yayasan akan memudahkan untuk pengalihan asset ini kepada lembaga yang sejenis yang tujuannya sama dengan Undang-Undang Yayasan.

Setelah mengalami perdebatan yang cukup panjang, maka sidang diskors pukul 12.00 WIB dan dicabut kembali pukul 12.30 WIB. Berdasarkan hasil lobby di antara fraksi-fraksi dan Komisi VIII, ini mengedepankan tenggang rasa dan saling hormat menghormati dan terjadi lobby dengan semangat persaudaraan dengan seluruh delegasi dan kepada Pimpinan Fraksi-fraksi lain, akhirnya disepakati solusinya sebagai berikut, ialah: masuk dalam ketentuan peralihan di Pasal 43 ayat (4) "LAZ sebagaimana dimaksud pada ayat (3) wajib menyesuaikan diri paling lambat 1 tahun terhitung sejak undangundang ini diundangkan, diganti menjadi paling lambat 5 tahun". Yang kedua, setelah kita gagas lagi tadi, saya terima kasih dari PDI Perjuangan mengingatkan sehingga ada klausul yang kita sisipkan di sini dan sangat bagus ialah Pasal 4 ayat (3) dalam penjelasannya "Yang dimaksud badan usaha di sini adalah badan usaha yang dimiliki oleh umat Islam".

Akhirnya setelah melalui proses dan perdebatan panjang, RUU tentang Pengelolaan zakat disahkan oleh DPR dan Pemerintah menjadi undang-undang di Jakarta pada tanggal 25 November 2011 dan masuk menjadi lembaran negara Republik Indonesia Tahun 2011 Nomor $115 .^{19}$

b. Materi UU No 23 Tahun 2011 tentang Pengelolaan Zakat

Undang-Undang Nomor 23 Tahun 2011 tentang Pengelolaan Zakat ini terdiri dari 11 (sebelas) bab dan 47 (empat puluh tujuh) pasal, yaitu:

- BAB I Ketentuan Umum, terdiri dari 4 (empat) pasal.

- BAB II Badan Amil Zakat Nasional, terdiri dari 4 (empat) bagian dan 16 (enam belas) pasal.

- BAB III Pengumpulan, Pendistribusian, Pendayagunaan Dan Pelaporan, terdiri dari 5 (lima) bagian dan 9 (sembilan) pasal.

- BAB IV Pembiayaan, terdiri dari 4 (empat) pasal.

- BAB V Pembinaan Dan Pengawasan, terdiri dari 1 (satu) pasal.

19 Risalah Resmi, Rapat Paripurna ke-9 2011-2012, Kamis, 27 Oktober 2011, Pukul 09.00 WIB s/d Selesai di Ruang Rapat Paripurna Gedung Nusantara II Jl. Jend. Gatot Subroto-Jakarta, 36 . 
- BAB VI Peran serta Masyarakat, terdiri dari 1 (satu) pasal.

- BAB VII Sanksi Administratif terdiri dari 1 (satu) pasal dan 2 (dua) ayat

- BAB VIII Larangan terdiri dari 2 (dua) pasal

- BAB IX Ketentuan Pidana terdiri dari 4 (pasal) dan 2 (dua) ayat

- BAB X Ketentuan Peralihan terdiri dari 1 (satu) pasal dan 4 (empat) ayat

- BAB XI Ketentuan Penutup terdiri dari 4 (empat) pasal

Dari amatan penulis yang sederhana ini, dapat diilustrasikan bahwa terwujudnya UU Zakat ini berasaskan syariat Islam; amanah; kemanfaatan; keadilan; kepastian hukum; terintegrasi; dan akuntabilitas. Dari asas ini dapat diketahui bahwa kemunculan UU zakat ini dalam rangka untuk meningkatkan efektivitas dan efisiensi pelayanan dalam pengelolaan zakat; dan meningkatkan manfaat zakat untuk mewujudkan kesejahteraan masyarakat dan penanggulangan kemiskinan, hal tersebut tercemin dari tujuan pengelolaan zakat dalam UU ini. ${ }^{20}$ Dalam UU ini juga terbahas beberapa catatan mengenahi ruang lingkup dan komoditas yang harus dizakati dan beberapa aktifitas ekonomi yang mengharuskan pelakunya untuk mengeluarkan, hal tersebut tercermin dalam pasal 4 (empat), walaupun keterangan lebih lanjut atau teknis operasionalnya akan diatur peraturan pemerintah dan peraturan menteri agama.

UU zakat yang sampai hari ini masih disengketakan oleh beberapa kalangan ini, lebih banyak mengatur tentang; pertama, keberadaan amil zakat (yang dalam hal ini diperankan oleh BAZNAS dan LAZ), kedua, mengatur tentang sistematika dan cara pengelolaan zakat yang profesional. Pernyataan ini bukan tanpa alasan, bayangkan dari 47 pasal yang ada pada UU Zakat ini, hampir separo lebih mengatur tentang BAZNAS/LAZ dan mekanisme tentang Pengelolaan zakat.

Disamping itu, dalam Undang-undang Nomor 23 tahun 2011 ini juga mengatur mekanisme pembentukan Badan atau Lembaga Zakat melalui surat keputusan menteri dan persyaratan pemberian izin bagi Lembaga Amil Zakat (LAZ) sehingga memudahkan BAZNAS mengontrol dan mengawasi LAZ yang tumbuh dan berkembang secara liar ditengah-tengah masyarakat. ${ }^{21}$ Sehingga Setiap orang

20 Lihat, UU No. 23/2011 tentang Pengelolaan Zakat pasal 2 dan pasal 3

21 UU No. 23/2011 tentang Pengelolaan Zakat Pasal 18:

1. Pembentukan LAZ wajib mendapat izin Menteri atau pejabat yang ditunjuk oleh Menteri. 
dilarang dengan sengaja bertindak sebagai amil zakat dengan melakukan pengumpulan, pendistribusian, atau pendayagunaan zakat tanpa izin pejabat yang berwenang dan akan dikenakan sanksi. ${ }^{22}$

Bila dibandingkan dengan UU No. 38 tahun 1999, maka UU zakat yang baru ini memiliki banyak perbedaan. Perbedaan ini bukan hanya bersifat asesoris, akan tetapi juga mencakup substansinya. Beberapa perbedaan mendasar antara UU No.38/1999 dengan UU No. 23/2011 antara lain adalah:

a. Pada Undang-undang lama, namanya adalah Undang-undang Tentang Pengelolaan Zakat, sementara Undang-undang Zakat baru namanya adalah UU Zakat, Infak dan Sedekah. Namun Ketika diasahkan tetap menjadi Undang-Undang Tentang Pengelolaan Zakat.

b. Pada Undang-undang lama, posisi pemerintah dan masyarakat sejajar dalam pengelolaan zakat, sementara dalam Undang-undang zakat baru posisi pemerintah dan atau badan zakat pemerintah (BAZNAS) lebih tinggi.

c. Pada Undang-undang lama, masyarakat dibebaskan untuk mengelola zakat, pada Undang-undang baru, hanya yang diberi izin saja yang boleh mengelola zakat.

d. Pada Undang-undang lama, pengaturan Lembaga Amil Zakat (LAZ) hanya dalam dua pasal, sementara pada UU baru, LAZ diatur dalam 13 pasal.

e. Pada Undang-undang lama, LAZ dibentuk oleh masyarakat, sementara pada UU baru, LAZ dibentuk oleh organisasi

2. Izin sebagaimana dimaksud pada ayat (1) hanya diberikan apabila memenuhi persyaratan paling sedikit:
a. terdaftar sebagai organisasi kemasyarakatan Islam yang mengelola bidang pendidikan, dakwah, dan sosial; (digugurkan oleh MK)
b. berbentuk lembaga berbadan hukum;
c. mendapat rekomendasi dari BAZNAS;
d. memiliki pengawas syariat;
e. memiliki kemampuan teknis, administratif, dan keuangan untuk melaksanakan kegiatannya;
f. bersifat nirlaba;
g. memiliki program untuk mendayagunakan zakat bagi kesejahteraan umat; dan bersedia diaudit syariat dan keuangan secara berkala.

22 UU No. 23/2011 tentang Pengelolaan Zakat Pasal 38 Setiap orang dilarang dengan sengaja bertindak selaku amil zakat melakukan pengumpulan, pendistribusian, atau pendayagunaan zakat tanpa izin pejabat yang berwenang, walaupun secara subtansial ketentuan ini digugurkan oleh MK, lihat, Putusan Mahkamah Konstitusi Nomor 86/PUU-X/2012 tanggal 31 Oktober 2013. 
kemasyarakatan Islam yang bergerak di bidang dakwah, sosial dan pendidikan. $^{23}$

f. Pada Undang-undang lama, aturan lanjutan Undang-undang semuanya akan diatur dalam Peraturan Menteri, sementara pada Undang-undang baru, sebagian besar diatur pada Peraturan Pemerintah. ${ }^{24}$

Namun demikian, ada beberapa catatan untuk UU zakat ini, sebagaimana yang disampaikan oleh beberapa pegiat zakat yang telah mapan. Pasal-pasal yang dianggap krusial dalam UU zakat ini antara lain:

- Pasal 5 ayat (1). Untuk melaksanakan pengelolaan zakat, Pemerintah membentuk BAZNAS.

- Pasal 7 ayat (1). Dalam melaksanakan tugas sebagaimana dimaksud dalam Pasal 6, BAZNAS menyelenggarakan fungsi: (a) perencanaan pengumpulan, pendistribusian, dan pendayagunaan zakat; (b) pelaksanaan pengumpulan, pendistribusian,dan pendayagunaan zakat; (c) pengendalian pengumpulan, pendistribusian, dan pendayagunaan zakat; dan (d) pelaporan dan pertanggungjawaban pelaksanaan pengelolaan zakat.

- Pasal 17. Untuk membantu BAZNAS dalam pelaksanaan pengumpulan, pendistribusian, dan pendayagunaan zakat, masyarakat dapat membentuk LAZ.

- Pasal 38. Setiap orang dilarang dengan sengaja bertindak selaku amil zakat melakukan pengumpulan, pendistribusian, atau pendayagunaan zakat tanpa izin pejabat yang berwenang. ${ }^{25}$

- Pasal 41. Setiap orang yang dengan sengaja dan melawan hukum melanggar ketentuan sebagaimana dimaksud dalam Pasal 38 dipidana dengan pidana kurungan paling lama 1 (satu) tahun dan/atau pidana denda paling banyak Rp50.000.000,00 (lima puluh juta rupiah). ${ }^{26}$

c. Badan Amil Zakat Nasional (BAZNAS) Sebagai Lembaga Independen

\footnotetext{
23 Ketentuan ini kemudian ditiadakan, karena termasuk materi yang digugat oleh sebagian organisasi LAZ, yang kemudian juga termasuk bagian yang dikabulkan oleh Mahkamah Konstitusi pada Putusan Mahkamah Konstitusi Nomor 86/PUU-X/2012 tanggal 31 Oktober 2013.

24 UU No. 23 Tahun 2011 tentang Pengelolaan Zakat

25 Ditiadakan oleh Putusan Mahkamah Konstitusi Nomor 86/PUU-X/2012 tanggal 31 Oktober 2013.

${ }^{26}$ Ibid.
} 
Salah satu hal terpenting dalam Undang-Undang No. 23 Tahun 2011 tentang Pengelolaan Zakat di antaranya adalah terkait dengan penguatan kelembagaan. Dalam Undang-undang ini BAZNAS (Badan Amil Zakat Nasional) disebutkan sebagai lembaga pemerintah non struktural yang merupakan perpanjangan tangan dari pemerintah. Dalam hal ini secara teknis BAZNAS di bawah koordinasi Kementerian Agama. Jika pada Undang-Undang Nomor 38 tahun 1999 yang duduk di BAZNAS disebut sebagai pengurus, maka di dalam Undang-Undang No. 23 Tahun 2011 tentang Pengelolaan Zakat, sebutan mereka tidak lagi sebagai pengurus, tapi anggota komisioner.

Selain itu, dalam UU nomor 23 tahun 2011 pasal 6 dan 7 ayat 1 dijelaskan, ${ }^{27}$ peran BAZNAS menjadi lembaga yang berwenang melakukan tugas pengelolaan zakat secara nasional. Fungsi BAZNAS disebutkan sebagai perencanaan, pelaksana, pengendalian baik dalam pengumpulan, pendistribusian, dan pendayagunaan zakat. Selain itu, pelaporan dan pertanggungjawaban pelaksanaan pengelolaan zakat. Dalam hal ini BAZNAS cukup punya kewenangan yang lebih. Jika kemampuan BAZNAS pada undang-undang nomor 38 tahun 1999 memiliki kewenangan yang terbatas sehingga dari sisi pengumpulan maupun pendistribusian kalah jauh dengan LAZ. Akan tetapi dengan kewenangan yang diberikan sekarang BAZNAS akan sangat leluasa dengan memiliki hirarki dan jaringan hingga tingkat struktur yang paling bawah bawah.

Proses perekrutan anggota komisioner BAZNAS akan dilakukan dengan terlebih dahulu membentuk tim khusus. "Tugas tim ini secara terperinci akan dijabarkan dalam Peraturan Pemerintah (PP) yang saat ini masih dalam tahap penyusunan. Sementara pengangkatan dan pemberhentian anggota komisioner dilakukan oleh Presiden atas usul

\footnotetext{
27 Pasal 6 BAZNAS merupakan lembaga yang berwenang melakukan tugas pengelolaan zakat secara nasional. Pasal 7 (1) Dalam melaksanakan tugas sebagaimana dimaksud dalam Pasal 6, BAZNAS menyelenggarakan fungsi: a. perencanaan pengumpulan, pendistribusian, dan pendayagunaan zakat; b. pelaksanaan pengumpulan, pendistribusian, dan pendayagunaan zakat; c. pengendalian pengumpulan, pendistribusian, dan pendayagunaan zakat; dan d. pelaporan dan pertanggungjawaban pelaksanaan pengelolaan zakat. (2) Dalam melaksanakan tugas dan fungsinya, BAZNAS dapat bekerja sama dengan pihak terkait sesuai dengan ketentuan peraturan perundangundangan. (3) BAZNAS melaporkan hasil pelaksanaan tugasnya secara tertulis kepada Presiden melalui Menteri dan kepada Dewan Perwakilan Rakyat Republik Indonesia paling sedikit 1 (satu) kali dalam 1 (satu) tahun. Keterangan lebih lanjut mengenahi BAZNAS dapat dilihat di UU No.23/2011 tentang Pengelolaan Zakat.
} 
menteri. Anggota komisoner BAZNAS akan disaring oleh tim seleksi yang prosesnya terbuka. Siapapun yang memenuhi syarat maka boleh ikut mendaftar. Tim pansel (panitia seleksi) nantinya bukan dari internal KEMENAG, tetapi dari berbagai unsur masyarakat seperti tokoh masyarakat, profesional, intelektual dan sebagainya. ${ }^{28}$

BAZNAS sebagai lembaga yang diatur secara definitif dalam undang-undang juga memiliki sifat mandiri. ${ }^{29}$ Namun, selain sifat mandiri, ada dua unsur lain yang diatur dalam Pasal tersebut, yaitu BAZNAS sebagai lembaga pemerintah non-struktural, dan bertanggungjawab kepada Presiden melalui Menteri Agama.

Disamping itu BAZNAS juga berfungsi unutuk mengawasi LAZ agar lebih transparan dan sesuai dengan apa yang dikehendaki oleh muzaki sehingga memang harus ada verifikasi secara lebih ketat dan profesional dalam menjalankan fungsinya. Adapun Badan atau Lembaga yang ditetapkan sebagai penerima zakat atau sumbangan meliputi: ${ }^{30}$

1. Badan Amil Zakat Nasional

2. LAZ Dompet Dhuafa Republika

3. LAZ Yayasan Amanah Takaful

4. LAZ Pos Keadilan Peduli Umat

5. LAZ Yayasan Baitulmaal Muamalat

6. LAZ Yayasan Dana Sosial Al Falah

7. LAZ Baitul Maal Hidayatullah

8. LAZ Persatuan Islam

9. LAZ Yayasan Baitul Mal Umat Islam PT Bank Negara Indonesia

10. LAZ Yayasan Bangun Sejahtera Mitra Umat

11. LAZ Dewan Da'wah Islamiyah Indonesia

12. LAZ Yayasan Baitul Maal Bank Rakyat Indonesia

13. LAZ Yayasan Baitul Maal wat Tamwil

14. LAZ Baituzzakah Pertamina

\footnotetext{
${ }^{28}$ Isbir Fadly, "Target Enam Bulan 8 PP dan 2 PMA Selesai", Majalah INFOZ+ Edisi I 16 Th VII Januari - Februari 2012, 08

${ }^{29}$ Undang-Undang Nomor 23 Tahun 2011 Pasal 5 ayat (3) BAZNAS sebagaimana dimaksud pada ayat (1) merupakan lembaga pemerintah nonstruktural yang bersifat mandiri.

${ }^{30}$ Hal itu sebagaimana dirilis oleh dirjen pajak dalam Peraturan Direktur Jenderal Pajak Nomor Per 15/Pj/2012 Perubahan Peraturan Direktur Jenderal Pajak Nomor Per33/Pj/2011 Tentang Badan/Lembaga Yang Dibentuk Atau Disahkan Oleh Pemerintah Yang Ditetapkan Sebagai Penerima Zakat Atau Sumbangan Keagamaan Yang Sifatnya Wajib Yang Dapat Dikurangkan Dari Penghasilan Bruto.
} 
15. LAZ Dompet Peduli Umat Daarut Tauhiid (DUDT)

16. LAZ Yayasan Rumah Zakat Indonesia

17. LAZIS Muhammadiyah

18. LAZIS Nahdlatul Ulama (LAZIS NU)

19. LAZIS Ikatan Persaudaraan Haji Indonesia (LAZIS IPHI)

20. Lembaga Sumbangan Agama Kristen Indonesia (LEMSAKTI)

21. Badan Dharma Dana Nasional Yayasan Adikara Dharma Parisad (BDDN YADP)

\section{UU Zakat Menuju Pengelolaan Zakat yang Profesional}

Sebelum berlanjut pada pembahasan tentang tujuan dari terciptanya profesionalitas dalam pengelolaan zakat ini, ada baiknya penulis uraikan terlenih dahulu tentang respon public (ulama' atau intelektual) terhadap upaya penyerahan Islam terhadap pengelolaan zakat kepada Negara. Ada banyak teori yang membahas tentang penyerahan pengelolaan zakat kapada pemerintah atau negara. Penyerahan ini menghasilkan kesepakatan bahwa pengelola pemerintah atau orang yang diamani oleh pemerintah tersebut adalah amil dalam zakat.

Amil adalah salah satu institusi yang dijelaskan dalam al-Qur'an (QS. Al-Taubah [9]: 60), yang memiliki peran penting dalam melakukan peran"intermediari" antara pihak yang memiliki surplus harta (Muzaki) dengan pihak yang mengalami defisit harta/mustadhafin (fakir, miskin, riqab, sabilillah, gharim, ibn sabil, dan mu'alaf). Analisis mengenai amil dalam hubungannya dengan pemerintah (baca: khlaifah/imam/amir) telah dikemukakan dan dibahas oleh Abu Ubaid dalam kitabnya, Kitâb alAmwâl. ${ }^{31}$

Dengan mengutip pendapat Ibn Sirin, Abu Ubeid menjelaskan bahwa: pertama, zakat pada zaman awal Islam diserahkan kepada Rasulullah atau kepada orang yang dipercayakan Rasulullah untuk mengelolanya (yang dimaksud orang yang dipercayakan Rasulullah untuk mengelola zakat adalah amil/amilin); kedua, pada zaman kekhalifahan Abu Bakar bahwa zakat diserahkan kepada Abu Bakar atau kepada orang yang dipercaya untuk mengelolanya; ketiga, zakat diserahkan kepada khalifah Umar pada zaman kekhalifahannya atau kepada orang yang telah dilantik untuk

\footnotetext{
31 Penjelasan mengenai riwayat tentang ikhtilaf ulama mengenai keharusan menyerahkan zakat harta kepada pemimpin atau amil yang ditunjuknya disarikan dari Kitab al-Amwal (khususnya pada bab daf'u al-s\{adaqah ila al-umarâ' wa ikhtilâf al-ulamâ fîhâ). Lihat Abû Ubaid al-Qâsim Ibn Sallâm, Kitâb al-Amwâl (Beirût: Dâr al-Syurûq. 1989), Cet.1, 675683;
} 
mengelolanya; dan keempat, zakat diserahkan kepada Utsman pada zaman kekhalifahannya atau kepada orang yang telah diresmikan untuk mengelolanya.

Ketika Utsman terbunuh, ulama berbeda pendapat sehingga berbeda dalam menyerahkan zakat. Di antara mereka ada yang masih menyerahkan zakat kepada para penguasa, dan ada juga di antara mereka yang membagikan zakat secara langsung, tanpa diserahkan kepada penguasa. Di antara orang yang masih menyerahkan zakat kepada penguasa adalah Ibnu Umar.

Ibnu Sirin menjelaskan bahwa apabila seseorang membagi zakat hartanya sendiri (tanpa memalui khalifah/amil), hendaklah dia bertakwa kepada Allah; janganlah mencela suatu kaum dengan cara apa pun; karena celaan itu dikhawatirkan akan menjadi pemicu lahirnya musibah yang sama atau lebih buruk dari tragedi yang telah terjadi. Sedangkan ulama lain, Ayub, menjelaskan bahwa akhir sirah tersebut adalah bahwa siapa saia yang membagikan zakat hartanya secara langsung, hendaklah ia bertakwa kepada Allah dan janganlah dia menutup-nutupi harta yang semestinya dikeluarkan zakatnya. Dengan demikian, aspek kejujuran dalam menghitung sendiri akan harta yang dizakati merupakan aspek yang sangat penting.

Sirah yang diriwayatkan Ibn Sirin juga mendapat penguatan dari praktek penyerahan zakat yang dilakukan oleh sahabat-shabat Nabi Saw yang lain, di antaranya Ummi Alqamah menjelaskan bahwa Aisyah Radhiyallah 'anha menyerahkan pembayaran zakat hartanya kepada pemimpin/khalifah.

Ulama kontemporer banyak mempertanyakan mengenai kualitas ketaatan umat kepada pemimpin yang melakukan penyimpangan (baca: tidak adil). Perdebatan ini berdampak juga terhadap pertanyaan: apakah zakat harta boleh diserahkan kepada khalifah/pemerintah yang melakukan penyimpangan? Suhail bin Abu Saleh meriwayatkan dari ayahnya mengenai jawaban atas pertanyaan tersebut. Suhail bin Abu Saleh dari ayahnya, ia berkata, "saya pernah bertanya kepada Sa'ad bin Abi Waqqash, Abu Hurairah, Abu Sa'id al-Khudri, dan Ibnu Umar. Lalu saya katakan kepada mereka, "sesungguhnya penguasa ini telah melakukan seperti apa yang telan kalian saksikan. Apakah saya harus menyerahkan zakat kepada mereka?" Seluruh sahabat itu menjawab, "Serahkan zakat hartamu kepada mereka!"

Ibnu 'Aun berkata, "Saya pernah bertanya kepada Mujahid mengenai zakat. Lalu ia berkata, "Abdullah bin 'Ubaid bin 'Umair berkata ketika dia sedang bertawaf bersama-sama kami, "sesungguhnya ada seorang 
lelaki pernah mendatangi Ibnu Umar membawa zakat hartanya. Lelaki itu berkata, "Wahai Abu Abdurrahman, ini adalah zakat hartaku. Lalu kemanakah saya harus menyerahkan dan meletakkan zakat hartaku ini?" Ibnu Umar menjawab, "serahkanlah zakat harta itu kepada orang yang telah engkau bai'at untuk menjadi penguasa.'" Ibnu "Aun telah menepukkan salah satu tangannya dengan lainnya. "Ubaid bin 'Umair berkata sambil mengangkat kepalanya, "Saya tidak akan membagikan zakat harta ini." Ibnu Umar berkata, "serahkan zakat harta itu kepada sultan/penguasa!" Lalu 'Ubaid bin 'Umair berkata, "tidak. Akan tetapi letakkanlah ia sebagaimana Allah telah memerintahkan kepadamu!"

Yusûf al-Qarḍ̂wi menjelaskan lima alasan mengapa Islam menyerahkan wewenang kepada negara untuk mengelola zakat. 1) Banyak orang yang telah mati jiwanya, buta mata hatinya, tidak sadar akan tanggung jawabnya terhadap orang fakir yang mempunyai hak milik yang terselip dalam harta benda mereka. 2) Untuk memelihara hubungan baik antara murakki dan mustabiq, menjaga kehormatan dan martabat para mustabiq. Dengan mengambil haknya dari pemerintah mereka terhindar dari perkataan menyakitkan dari pihak pemberi. 3) Agar pendistribusiannya tidak kacau, semraut dan salah atur. Bisa saja seorang atau sekelompok orang fakir miskin akan menerima jatah yang berlimpah ruah, sementara yang lainnya yang mungkin lebih menderita, tidak mendapat jatah zakat sama sekali. 4) Agar ada pemerataan dalam pendistribusiannya, bukan hanya terbatas pada orang-orang miskin dan mereka yang sedang dalam perjalanan, namun pada pihak lain yang berkaitan erat dengan kemaslahatan umum. 5) Zakat merupakan sumber dana terpenting dan permanen yang dapat membantu pemerintah dalam menjalankan fungsi-fungsinya dalam mengayomi dan membawa rakyatnya dalam kemakmuran dan keadilan yang beradab. ${ }^{32}$

Lantas dalam konteks UU zakat di Indonesia ini, ada alasan bagi pemerintah dan DPR untuk mengajukan UU zakat, yaitu; zakat apabila dikelola dengan baik, ${ }^{33}$ terdapat potensi dan sumber dana yang dapat dimanfaatkan untuk pengentasan kemiskinan, mewujudkan kesejahtraan dan keadilan sosial. Selama ini pengelolaan zakat di Indonesia, baik yang

\footnotetext{
${ }^{32}$ Lihat: Yusûf alQardhâwi, Fiqh al-Zakâh, (Beirût: Dâr al-Irsyâd, t.th), 756-757

33 Maksud dari mengelola dengan baik dalam kajian ini adalah, diatur regulasinya, tata cara pengelolaanya, keterlibatan masyarakat dalam mengelola, walupun dengan pengawasan yang ketat dan akuntabel dari pemerintah sebagai regulatornya, dengan sistem inilah barangkali akan tercapai pemanfaatan potensi zakat yang melimpah ruah itu.
} 
dilakukan oleh lembaga sosial keagamaan ataupun badan amil zakat belum maksimal dan terkesan kurang professional. ${ }^{34}$

Akhirnya, implementasi sistem zakat akan dapat mengurangi kemiskinan dan sebagai alternative penanggulan pengangguran yang menjadi penyakit dalam pembangunan perekonomian suatu wilayah akan dapat teratasi secara sinergis dengan beberapa program pemerintah yang sejalan.

Tentunya, implementasi pengembangan ekonomi zakat membutuhkan keterlibatan pemerintah, muzakki dan mustahik. Semua pihak harus peduli dan bekerja keras dalam mewujudkannya. Jika tidak, berarti sama saja dengan membiarkan ketidakadilan ekonomi terjadi. Pengelolaan secara profesional dapat meningkatkan kesadaran muzakki dalam penunaian zakat. Karena masih ada umat Islam yang kaya (mampu) belum menunaikan ibadah zakatnya, bukan karena persoalan kemampuan, akan tetapi karena kurangnya pengetahuan dan kesadaran berzakat. Penunaian zakat akan membangkitkan solidaritas sosial, mengurangi kesenjangan sosial dan pada gilirannya akan mengurangi derajat kejahatan di tengah masyarakat. Untuk ini, pemerintah, BAZ atau LAZ harus memiliki database mengenai muzakki dan mustahik di wilayah kedudukannya.

Dengan pelaksanaan zakat oleh negara akan menunjang terbentuknya keadaan ekonomi yang growth with equity, peningkatan produktivitas yang dibarengi dengan pemerataan pendapatan serta peningkatan lapangan pekerjaan bagi masyarakat.

Maka dari itu, sangat tepat jika M. A. Mannan dalam Islamic Economics: Theory and Practice, menyebut zakat sebagai aktifitas ekonomik religius, sesuai dengan prinsip-prinsip berikut; 1) Prinsip kepercayaan keagamaan (faith), bahwa orang yang membayar zakat menyakini pembayarannya itu merupakan salah satu manifestasi dari keyakinan agamanya. Sehingga apabila ia belum melunasi zakat maka akan merasakan ibadahnya belum sempurna. 2) Prinsip pemerataan (equity) dan keadilan yang menggambarkan tujuan zakat, yaitu membagi lebih adil kekayaan yang telah diberikan Tuhan kepada umat manusia. 3) Prinsip produktifitas dan kematangan, yang menekan bahwa zakat harus dibayar sesuai dengan hasil produksi setelah lewat waktu satu tahun, ukuran normal diperolehnya suatu penghasilan. 4) Prinsip nalar (reason) dan kebebasan (freedom), menjelaskan bahwa zakat hanya dibayar oleh orang yang sehat jasmani dan rohaninya, yang merasa mempunyai tanggung jawab untuk

${ }^{34}$ Lihat, Jazuni, Legislasi Hukum Islam di Indonesia, (Bandung: Citra Aditnya, 2005), 411 
membayarkannya demi kepentingan bersama. Karenanya, zakat tidak disahkan dipungut dari orang yang sedang dihukum atau orang yang sedang sakit jiwa. 5) Prinsip etika dan kewajaran, yang menyatakan bahwa zakat tidak bisa ditarik secara semena-mena tanpa memperhatikan akibat yang ditimbulkan oleh penarikan itu. ${ }^{35}$

\section{Kesimpulan}

Dari uraian yang telah jelaskan dimuka ada beberapa kesimpulan yang dapat disampaikan dalam makalah ini, antara lain;

Pertama, Dapat dikatakan bahwa, sejarah tentang regulasi zakat di Indonesia diwarnai dengan pergulatan yang sangat panjang, serta tarik ulur antara kepentingan Islamis politik dan kepentingan Islamis kultural dan bahkan kepentingan kolonial penjajah dalam upaya mengatur undang-undang zakat. Hal itu dimulai dari zaman kolonial penjajah, dengan adanya Bijblad Nomor 1892 tanggal 4 Agustus 1893 yang berisi tentang kebijakan Pemerintah Kolonial mengenai zakat, sebuah aturan yang terkesan berupaya mengatur tentang sistem administrasi zakat, akuntabilitas laporanya. Kemudian dikeluarkan Bijblad Nomor 6200 yang berisi tentang pelarangan bagi seorang pegawai dan priyayi pribumi untuk membantu pelaksanaan zakat. Selanjutnya adalah era pasca-penjajahan, dalam hal ini perhatian pemerintah terhadap lembaga zakat semakin meningkat pada tahun 1968. Yaitu dengan dikeluarkannya Peraturan Menteri Agama Nomor 4 dan Nomor 5 Tahun 1968, masing-masing tentang pembentukan Badan Amil Zakat dan Baitul Mal (Balai Harta Kekayaan) di tingkat pusat, propinsi, dan kabupaten/kota, namun demikian keputusan ini diikuti oleh keputusan Menteri Agama baru yang berisi tentang penundaan pelaksanaan Peraturan Menteri Agama Nomor 5/1968. Masih pada tahun yang sama, Presiden Suharto, pada malam peringatan Isra' Mi'raj di Istana negara tanggal 22 Oktober 1968, mengelurkan anjuran untuk menghimpun zakat secara sistematis dan terorganisasi. Anjuran ini kemudian ditindaklanjuti oleh oleh Pemerintah Daerah Khusus Ibukota Jakarta Raya, yang pada waktu itu dipimpin oleh Gubernur Ali Sadikin, untuk mengelola zakat secara professional, maka berdirilah Badan Amil Infaq dan Shadaqah (BASIS). Hal ini diikuti oleh berbagai propinsi di Indonesia, yaitu dengan terbentuknya Badan Amil Zakat yang bersifat semi pemerintah melalui surat keputusan Gubernur. Badan tersebut tampil dengan nama yang berbeda-beda disetiap daerah,

35 Ahmad Wahyu Herdianto, "Peran Negara Dalam Mengoptimalkan Zakat Di Indonesia", Jurisdictie; Jurnal Hukum Dan Syariah, Vol.1, No.2, Desember 2010, 14-15. 
namun pada umumnya mengambil nama BAZIS seperti di Aceh (1975), Sumatra Barat (1977), Lampung (1975), Jawa Barat (1974), Kalimantan Selatan (1977), Kalimantan Timur (1972), Sulawesi Utara, Sulawesi Selatan (1985), dan Nusa Tenggara Barat. Sampai akhirnya munculnya UU Nomer 38 Tahun 1999 dan UU Nomer 23 tahun 2011 tentang pengelolaan zakat.

Kedua, Regulasi zakat ini perlu diatur oleh Negara, adalah dalam rangka untuk meningkatkan efektivitas dan efisiensi pelayanan dalam pengelolaan zakat; dan meningkatkan manfaat zakat untuk mewujudkan kesejahteraan masyarakat dan penanggulangan kemiskinan. Efektifitas dan efesiensi pengelolaan zakat di Indonesia yang majemuk ini, membutuhkan adanya kepastian hukum dan kejelasan regulasi yang mengaturnya. Selain itu, regulasi zakat ini dimunculkan dalam upaya penertiban pengelola zakat (amil) yang berasaskan pada prinsip-prinsip; syariah, amanah, kemanfaatan, keadilan, kepastian hukum, terintegrasi, dan akuntabilitas. Jika hal demikian itu tercipta, maka kesadaran masyarakat dalam berzakat akan tinggi dan zakat dapat digunakan sebagai alternative mewujudkan kesejahteraan masyarakat dan penanggulangan kemiskinan.

\section{Daftar Pustaka}

Qarḍ̂wîi (al), Yûsûf. Fiqh al-Zakâh. Beirut: Dâr al-Irshâd, t.th.

Sallâm, Abû 'Ubaid al-Qâsim Ibn. Kitâb al-Amwâl. Beirut: Dâr al-Shurûq, 1989.

Asnaini. "Membangun Zakat Sebagai Upaya Membangun Masyarakat" Dalam Jurnal La_Riba. Volume IV No. 01 Juli 2010.

Sakti, Ali. Ekonomi Islam; Jawaban atas Kekacanan Ekonomi Modern. Jakarta: Paradigma dan Aqsa Publishing, 2007.

Pribadi, Ancas Sulchantifa. "Pelaksanaan Pengelolaan Zakat Menurut Undang-Undang Nomor 38 Tahun 1999 Tentang Pengelolaan Zakat (Studi Di Baz Kota Semarang)", Tesis Program Studi Magister Kenotariatan Universitas Diponegoro Semarang Tahun 2006.

Ali, M. Daud. Sistem Ekonomi Islam Zakat dan Wakaf. Jakarta: UI Press, 1988.

Effendi, Djohan, dkk. Agama dalam Pembangunan Nasional (Himpunan Sambutan Presiden Suharto). Jakarta: CV. Kuning Mas, 1984. 
Amin, M. Mansyhur. Pengelolaan Zakat dan Permasalahannya di Indonesia. Jakarta: Direktorat Urusan Agama Islam Departemen Agama, 2000.

Kurniawan, Puji. "Legislasi Undang-Undang Zakat" dalam Jurnal AlRisalah. Volume 13 Nomor 1 Mei 2013.

Risalah Resmi, Rapat Paripurna ke-9 2011-2012, Kamis, 27 Oktober 2011, Pukul 09.00 WIB s/d Selesai di Ruang Rapat Paripurna Gedung Nusantara II Jl. Jend. Gatot Subroto-Jakarta.

Fadly, Isbir. "Target Enam Bulan 8 PP dan 2 PMA Selesai". Majalah INFOZ+. Edisi I 16 Th VII Januari-Februari 2012.

Herdianto, Ahmad Wahyu. "Peran Negara Dalam Mengoptimalkan Zakat Di Indonesia" Dalam Jurisdictie; Jurnal Hukum dan Syariah. Volume 1 Nomor 2 Desember 2010.

Jazuni. Legislasi Hukum Islam di Indonesia. Bandung: Citra Aditnya, 2005.

Undang - Undang No 38 Tahun 1999 tentang Pengelolaan Zakat. edc. Lama.

Undang - Undang No 23 Tahun 2011 tentang Pengelolaan Zakat. edc. Baru.

Peraturan Direktur Jenderal Pajak Nomor Per-15/Pj/2012 Perubahan Peraturan Direktur Jenderal Pajak Nomor Per-33/Pj/2011 Tentang Badan/Lembaga Yang Dibentuk Atau Disahkan Oleh Pemerintah Yang Ditetapkan Sebagai Penerima Zakat Atau Sumbangan Keagamaan Yang Sifatnya Wajib Yang Dapat Dikurangkan Dari Penghasilan Bruto. 